\title{
(Mis)representation among U.S. study abroad programs traveling to the African continent: A critical content analysis of a Teach Abroad program
}

\section{Ifeyinwa Onyenekwu}

Rutgers University

\section{Julianne Marie Angeli Ransford Pinto Ty-Ron Douglas \\ University of Missouri}

The Institute for International Education's Annual Open Doors Report (2014) indicates that less than $5 \%$ of study abroad college students travel to sub-Saharan African countries, with South Africa being the only African country to make the top 25 study abroad destinations for U.S. students, and it attracts only $1.8 \%$ of all collegians. Study abroad is defined as "educational programs that take place outside of the geographical boundaries of the country of origin (citing Kitsantas, 2004 in Lowe, Dozier, Hunt-Hurst, \& Smith, 2008, p. 738). It consists of combined coursework demonstrations, experiential activities, and tours sponsored by U.S. colleges and non-educational organizations. Programs vary in length from a full year to mini-semesters. The majority (74.3\%) of study abroad participants are White and $65.3 \%$ are women (Institute for International Education, 2014). Similarly, the majority of U.S. K-12 teachers are white women (National Center for Education Statistics, 2013).

There are both real and perceived challenges for study abroad programs that send students to African countries (Lowe et al., 2008). The negative portrayal of Africa in the American media and education system is largely responsible (Kiem, 2008; Onyenekwu, 2016; Pires, 2000). African students in the U.S. have recently shared such sentiments. Inspired by the Black Harvard students' campaign "I, too, am Harvard"; African-led campaigns have been raising awareness of African student experiences on U.S. college campuses. For example, on February 14, 2014 CNN published a short piece about the Ithaca College in New York Student Association's photo campaign called "The Real Africa: Fight the Stereotype." The student organization aimed to disprove common perceptions by adding quotes, such as "Africans don't need to be saved", to photos. Africans have launched similar campaigns, such as The Africa They Never Show You, across the globe on social media websites (e.g. Twitter) with the purpose of challenging stereotypes about the continent. These movements have signaled that Africans are not only aware of the single story that is being told about them but that they are resisting the stereotypes by taking action. 
Commonly held views that African countries lack political stability, national security, and resources are some of the reasons why American students decide not to study abroad in African countries (Onyenekwu, 2016; Pires, 2000). Lowe, Dozier, Hunt-Hurst, and Smith (2008) add that finances, parents' concerns, mass media, and widely held negative stereotypes of famine, poverty, and disease also prevent students from choosing to study abroad in African countries. While economic and institutional hurdles may be difficult to navigate, photos play a critical role in students' decision-making processes (Caton \& Santos, 2009).

The trend of representing Africa as a collection of negatives (i.e. famine, disease, poverty) has been well documented in higher education and has been embraced by academia without much resistance or critical engagement about the deficit-based ideologies that produce and sustain these problematic narratives (Caton \& Santos, 2009; Mama, 2007; Pires, 2000). This prevailing and pathological view of continental Africa should be concerning for colleges and universities. This study aims to make the connection between mass media and higher education by analyzing the content of promotional materials for study abroad programs in two sites of one program in Tanzania and South Africa.

We argue that postsecondary institutions need to do more to foster a balanced understanding of the African continent and one way this can be done is by improving the representation of the continent in study abroad promotional materials. While existing literature in the field of tourism, social work, and African studies have analyzed images of the cultural Other in study abroad texts, there is a paucity of higher education and student affairs research that utilizes postcolonial theory to analyze representations of Teach Abroad programs. To address this gap, this research undertakes a critical content analysis of promotional literature of one program, Instruct in Africa (pseudonym), to determine whether representations differ from the dominant. We end our article with suggestions for study abroad directors and those who create marketing and promotional tools so they can improve the ways they represent the continent and their students' experiences there.

\section{Literature Review}

The United States sent 280,408 college students to study abroad during the 2012-2013 academic year (Institute of International Education, 2014). While these programs varied considerably in duration and type, studies identify positive outcomes for students who participate. For instance, research finds that study abroad college students have better academic performance (Luo \& Jamieson-Drake, 2014), stronger intercultural communication skills (Salisbury, Umbach, Paulsen \& Pascarella, 2009; Williams, 2005), a sense of global citizenship (Wynveen, Kyle \& Tarrant, 2012), and greater maturity (DeGraaf, Slagter, Larsen \& Ditta, 2013). In addition, students gain personal, academic, and professional opportunities while universities promote study abroad offerings to acquire international recognition for their institution abroad (Bishop, 2013). To this end, universities and colleges are increasing the number of study abroad programs and offering a wider variety of destinations. Universities are using a number of mediums such as websites, print posters, brochures and flyers to advertise and promote study abroad. The aforementioned literature on study abroad suggests that individual factors enhance intent and individual outcomes; however, there is a paucity of research that has paid attention to the promotional materials directed at students and what messages about study abroad these materials are transmitting. 
Existing studies find that study abroad promotional materials depict orientalist biases (Mukherjee \& Chowdhury, 2014; Said, 1978), 'Othered' representations of hosts and host culture (Caton \& Santos, 2009), and use consumerism to represent study abroad trips as tourism (Bishop, 2013; Woolf, 2006). Literature on western mass media find that representations of the Global South rely on poverty porn (Glick, 2015) and the White Savior Complex (Cole, 2012; Brown, 2013) to provoke emotional responses from Westerners, which furthers misconceptions about the developing world.

\section{Promotional Materials}

Orientalism. Orientalism, as described by Said (1978), is the set of assumptions and stereotypes, which present primarily non-Western cultures as valued mainly for their history rather than their capacity for contributing to the world. It privileges the opinions of non-Eastern voices weighing in on the East, and locks the East in a binary with Europe or the West, wherein the East is deemed inferior (Said, 1978). Mukherjee and Chowdhury (2014) employed orientalism as a framework to conducted a qualitative content analysis of flyers advertising study abroad opportunities sponsored by U.S. social work schools, arguing that using orientalist stereotypes for marketing purposes can affect students' social behavior and learning while abroad. They indicated overuse of historical stock photos relative to images indicating the academic purpose of the programs. While this study examined a similar type of program-sponsored by academic departments with a practice focus-it concentrated on broad representations of destinations, excluding host interactions with participants.

'Othered' representations. Caton and Santos (2009) similarly used qualitative content analysis to examine marketing images for Semester at Sea (SAS) using a postcolonial framework. Images broadly essentialized the differences between host individuals and cultures and participants. Hosts were depicted primarily in 'ethnic' clothing, the few images depicting interactions between hosts and participants showed hosts as objects or performing service to participants, and destination photos overwhelmingly represented historical structures, ruins, and landscapes versus the high-tech presentation of the ship. While this study focused on representations of host versus participant culture and interactions, it used a nonprofit provider program marketing broadly to participants from many universities.

Representations of study abroad images have tremendous power to affect students' experiences abroad by allowing them to imagine themselves in the country and shaping their expectations, behavior, and attitudes (Bishop, 2013; Mukherjee \& Chowdhury, 2014). Highlighting differences through images allows students to envision themselves in new settings while relying on existing misconceptions or stereotypes about the lived realities of hosts. These representations are unchallenged and reproduced throughout the experience, and privilege the backgrounds of participants over hosts.

Consumerism in study abroad. Consumerism undergirds the discussion of exploiting orientalist stereotypes in study abroad marketing images. Consumerism in a study abroad context is buying experiences, "expect[ing] that a culture that took thousands of years to form will be quickly and easily available to" participants (Bolen, 2001, p. 186). Notably, study abroad is marketed as tourism, but tourism that promises increased cultural competency and other positive personal 
outcomes. Study abroad has increasingly turned to mass marketing strategies to attract participants (Bolen, 2001), including using images confirming orientalist stereotypes to achieve this goal (Martin \& Griffiths, 2012; Woolf, 2006).

Bishop (2013) applied rhetorical analysis to images on study abroad websites of five major U.S. sending institutions to examine how these images may 'ideologically frame not only students' travel experiences, but also their perceptions of their societal positions within cultures other than their own" (p. 400). The images chosen to represent study abroad experiences to students present a visual framework for students to consider themselves in study abroad; therefore, the implicit messages in study abroad promotional imagery have an impact on students' expectations for the program (Mukherjee \& Chowdhury, 2014).

\section{Mass media stereotypes}

Presenting orientalist stereotypes in the context of service programs abroad invokes the "White Savior' complex constructed in popular films and literature. A 'White Savior' represents "unintentional, passive, 'colorblind' or dysconscious racism" (Brown, 2013, p. 131) which impedes critical conversations about the global structures privileging and oppressing. Acting within this complex are individuals who believe enthusiasm can solve the world's problems, and prioritizes the needs of privileged - predominately white-people to have deep emotional experiences, rather than to challenge systems of oppression (Cole, 2012). 'Poverty porn' or images attempting to elicit an emotional response using shocking depictions of poverty, natural disaster, or crisis (Glick, 2015), reproduce orientalist myths of an irrational, weak East, defined by the fact it is not Europe (Said, 1978). These pictures seek to draw students based on the "seductive images of exotica" (Woolf, 2006, p. 137).

This study will expand on the work done by Mukherjee and Chowdhury (2014) and Bishop (2013) by examining images used to promote faculty-led study abroad programs in non-traditional destinations in African countries (Geiser, 2015). Specifically, this study reviews promotional material from teach abroad programs sponsored by a college of education at a large, research 1, Midwestern institution which sent students to South Africa and Tanzania.

The study begins to explore the question of educational representational dynamics through an analysis of one study abroad program, Teaching Abroad. Collaborating with NGOs and a variety of campuses on the continent, TA is a program that offers undergraduate students the opportunity to spend a mini semester (4-6 weeks) studying abroad. The TA program was specifically chosen for the current study because of its stated mission to help students become responsible professionals and citizens appreciating and understanding different cultures, belief systems, values and languages. More specifically, the study attempts to identify whether the TA program "reproduces repressive and/or liberating discourses" (Pritchard, 2000) through its use of images in its official brochures and on its website. The study also will consider how student participants are represented within their sponsoring area, with respect to race/ethnicity and gender, and comparatively between programs in Europe and in Africa. Finally, the narrative associated with these images will be interrogated using a post-colonialist framework (Spivak, 1990; Said, 1978). These works discussed study abroad promotional materials for social work programs, nonprofit program providers, and large institutions broadly. 


\section{Theoretical Framework}

Postcolonial theory is a valuable resource for interrogating the ramifications of study abroad materials because of its power as a framework to identify and critique the rationalizations and expressions of the White colonial mindset (Fanon, 1952; Said, 1978). Postcolonial theory is rooted in the belief that colonialism has been and continues to be "one of the most compelling influences on the West's interpretations of and interactions with people from different (mainly non-Western) cultures (Echtner \& Prasad, 2003). It is concerned with the "system[s] of discourse by which the 'world' is divided, administered, plundered, by which humanity is thrust into pigeonholes, by which 'we' are 'human' and 'they' are not' (Said 1978, p. 41). Orientalism in the context of postcolonial theory sets up binaries between the East and the West to justify the exploitation of the East by the West (Caton \& Santos, 2009). Postcolonial theory seeks to identify and challenge the legacies of colonialism, including these myths, in contemporary institutions and practices.

Postcolonial scholars recognize and seek to call attention to the power imbalances that exist on economic and ideological levels between the West and the rest. In this scenario, the West occupies a privileged, authoritative and central ideological position, marginalizing the latter to the peripheries. Drawing on this framework, previous studies on study abroad in Africa have brought attention to the many ways in which western superiority is supported through imagery. This study will use postcolonial theory as a lens through which to identify themes represented in Teach Abroad marketing images, which buy into orientalist myths and exploit the global South.

In using postcolonial theory in this paper, we are acknowledging that tensions and intersections exist between colonialism, racism, and imperialism in U.S. education and policy discourses, particularly as it relates to black and brown space and black and brown people. Notably, postcolonial theory provides an analytical lens for interpreting the history of imperialism, the various strands of colonialism that have been historically informed by imperialism, and the contemporary realities that are a manifestation of the history of imperialism and postcolonialism today (Kennedy, 2000). With these considerations, one can better understand how study abroad materials can be an exemplification of White imaginative understandings and approaches to a Black, subaltern, and (more specifically in this paper) African peoples and lands that can be exoticized and exploited in the name of education. We concur with Khalifa, Douglas, and Venzant-Chambers (2016) who note:

Postcolonial theory is useful in clarifying the White imaginative. We understand the White imaginative to be perceptions, notions, descriptions, thoughts, or assumptions that White people have of people of color that are based on racialized stereotypes. The White imaginative is not necessarily coterminous with White people, as many White people may not actively choose not to embrace its orientations; and given its normalcy, many Blacks or Latinos are likely to have assumed White imaginative epistemologies, either knowingly or inadvertently. (p. 10)

Postcolonial theory demands that we ask questions like "education for whom?...for what purpose?..." and, specific to our analysis of study abroad promotional materials, "education and interpretation through whose lens?" There are also epistemological dynamics to consider. In particular, postcolonial theory requires that we reflect on our ways of knowing the communities, countries, and contexts under investigation (Douglas \& Nganga, 2015; Douglas, 2016). 
Leading postcolonial scholars (see Bhabha, 1994; Gresson, 2008; Said, 2012; Spivak, 1990, 1999; Spivak et al., 1996) challenge us to never forget that "postcolonial theory is a direct response to the historical legacy and present-day posturing of powers, policies, and political systems that have been constructed to oppress and exploit the resources of the subaltern Other" (Khalifa, Douglas, \& Venzant-Chambers, 2016). As a programmatic initiative within universities - universities that are typically reflective of white ideologies, led by white leaders, and programs that primarily send and serve white students on these overseas educational excursions - study abroad programs can easily serve as a sanitized strand of a controlling colonialist mindset that commissions the next generation of white students to learn about (not from or with) the subaltern subjects in colonizing lands. Villaverde (2008) notes that "[p]ostcolonialism has contributed greatly to the ways we theorize about power and resistance, which has been extremely useful in shifting national conceptions of authority and privilege" (pp. 81-82). It is the "national conceptions"-our ways of supposedly knowing, seeing, and stereotyping African people and spaces in study abroad materials - that we seek to analyze through our critical content analysis of promotional material of a teach abroad program.

\section{Methods}

This study centers around the following research questions: Do the representations of African countries and its people in study abroad promotional materials go beyond western mass media stereotypes? What messages do the images portray?

\section{Data Set}

The data chosen for this study are the images that appear in various forms of promotional materials (i.e., website, magazines, flyers, reports, newsletters, and brochures) that were advertised for students during the fall 2015 semester at Central University (CU; a pseudonym). This predominantly white institution is located in the Midwest region of the United States, and sends over 1200 students to study abroad annually. During the 2013-2014 school year, about one hundred and forty students traveled to the African continent for study abroad. Images from the website and posters serve as the primary source of advertisement, and are what students view when they are searching for information on study abroad. While the table below shows the number of study abroad images from the African continent by college, we decided to focus on the images from Central University's College of Education Teach Abroad program (hereafter TA) because of our professional and academic background in P-20 education. This faculty-led program sends undergraduate students to teach in South Africa and Tanzania for 3-6 weeks. This program carries academic credit, which means that students enroll in a class in order to participate. The mission is to provide students with experiences that will enhance their cultural competency and prepare them to be global citizens.

Table 1. Number of study abroad images from the African continent by college at Central University.

\begin{tabular}{|l|l|l|l|l|l|}
\hline & School of Journalism & School of Nursing & Public Health & Social Work & College of Education \\
\hline Ghana & 8 & 18 & 97 & 0 & 0 \\
\hline South Africa & 9 & 0 & 0 & 38 & 1 \\
\hline Tanzania & 0 & 0 & 0 & 0 & 16 \\
\hline
\end{tabular}




\section{Researcher's Positionality}

The first author is an assistant professor, and one of her areas of interest is diverse Black populations in higher education. Her personal and professional experience as the daughter of Nigerian immigrants, social justice educator, college administrator, and scholar practitioner sparked interest in the topic of representation of the African continent in study abroad materials. The second author is a female white American graduate student and Fulbright alumna who was an English teaching assistant in Turkey. She also studied abroad as an undergraduate student, and has served as a staff member on a weeklong service trip to Nicaragua. The third author is a male international doctoral student from Ghana who served as a project coordinator for the University of Cambridge on international exams. The fourth author is Bermudian / African-American scholar and an assistant professor who studies Black identities and community-based educational spaces across the Black Diaspora; he has also served as an instructor for a study abroad program to South Africa. All authors' interests have grown after reading literature on representation of the cultural other, and seek to understand the role U.S. higher education plays in preparing college students for study abroad in nontraditional destinations like the African continent.

\section{Data Analysis}

The 16 images collected from TA were the focus of our analyses. The first three authors independently coded the data sample. In analyzing the narrative that underpins the promotional materials and advertisement of TA, the researchers used semiotic analysis. Roland Barthes (1972) explained that semiotic analysis focuses on the messages that are communicated through cultural signs. We chose semiotic analysis because it provides us with a systematic way of carefully examining and making meaning of the 16 images under consideration. The analysis was a two-phase process consisting of denotation and connotation. As Barthes (1972) argues, images have a denotative (the basic description of a sign) and a connotative (the meaning we make from a sign) meaning.

Team members individually reviewed all the 16 images and completed memos to capture the denotative meaning of the images. For instance, the denotation of one photo might be: A pale white woman with brown hair holds out what seems to be an index card. Her body is largely cut off in the photo, and her face is turned away from the camera. Six dark skinned children stand around her, looking at the card or at her. They all appear young and most are wearing red clothing. One child appears scared or nervous, another appears confused. One looks up at the woman, while another looks at the younger child staring up at the woman. Behind the group is a dirt road. On the right of the road is a plain brown building with two large windows and three smaller windows. Banana or plantain trees are behind the building.

Individual team members independently documented the connotation of the images. In relation to the photo cited above, one connotative meaning is that teaching and learning in the photo is happening outside — why not in a classroom? — raising questions about facilities and suggesting a lack of support for education within the country. Finally, during the semiotic analysis the research team came together to share and compare their notes. The research team discovered and noted emerging themes, which were then developed into 23 codes to form our data. These 23 codes were, however, collapsed into three main themes and nine sub themes. Table two is an illustration of our results after codes were put into themes and sub-themes. 


\section{Trustworthiness and Limitations}

The researchers acknowledge that their positionalities and/or identities influence the study and shape the interpretations. As mentioned earlier, the research team included one postdoctoral scholar and two graduate students in education. Also, two research team members self-identify as African. While we acknowledge that our identities influence our worldview and elucidations, several steps were taken by the research team to enhance the validity of the findings. The team employed a multistep strategy to construct and validate the consistent use of coding. Drawing from Barthes (1972), we followed the connotation and denotation of the semiotic analysis method by beginning with first phase coding and second phase coding as described earlier. We reexamined, refined, and created new codes as needed to enhance reliability. Furthermore, we were trained to interpret data and triangulated amongst the group to enhance validity. For example, the researchers reviewed each other's memos and came to a consistent interpretation across the group.

While we utilized rigorous qualitative methods to enhance the reliability of our results, we acknowledge that there are limitations to this study. It is uncertain that findings are consistent amongst all those who conduct semiotic analysis on promotional materials. But the goal of this study is to better understand how Africa is being represented in study abroad materials in U.S. higher education institutions. We recommend that researchers conduct future work in this area, and we are in the process of conducting further work.

\section{Results}

Table 2. Themes and Sub-Themes of Study Abroad Images

\begin{tabular}{|l|l|}
\hline THEME/SUB-THEMES & TOTAL \\
\hline CHILDREN AS PROPS & \\
\hline Only white adults and black children & 10 \\
\hline Child being held & 4 \\
\hline Women as center & 2 \\
\hline & \\
\hline INSTRUCTION & \\
\hline Classroom & 4 \\
\hline Teaching & 2 \\
\hline & 12 \\
\hline ENVIRONMENT & \\
\hline Non-teaching & 14 \\
\hline Non-classroom & \\
\hline Poverty porn & 12 \\
\hline
\end{tabular}




\section{Findings}

Examining the photos revealed orientalist tropes and mass media representations that are consistent with the aforementioned literature on the African continent and its people. The broad symbolic themes are noted below.

\section{Children as Props}

We found that in most of these photos only White adults were with Black children and children were being held by White women. These photos with Black children largely relegated them to an object position, where they were used as a prop for White subjects to display their African experience. The Black children represented in the photos were small in stature. When Black children were shown without an adult in the photo, they were either looking out of frame, smiling vaguely at an unknown subject, or dressed in dirty, shabby clothes, looking sad, frightened, and dejected. The most frequent depictions were in posed groups or seated in a classroom, with their backs to the camera.

Only White adults and Black children. Of the 13 photos in the subset, eleven images showed adults present; in ten of these photos, the adults present were only White women. The photos depicting only White adults and Black children included a large group photo with a White woman at the center of a group of Black children, presumably a class; a close-up photo of a White woman holding a Black child; or a White woman at the front of a classroom with Black children sitting in desks. While White women are by far the largest demographic of teachers in the U.S. and study abroad participants, it is important to note that local teachers were absent in the majority of the images. The children and the adults were racially very distinct; in one case, the White woman wore all white clothing while the children gathered around her wore dark colored clothing. In another, the White woman wore a blue shirt while all the children wore red. In classroom photos, the students wore uniforms. Absent from the photos were Black educators; only one photo including Black adults, but this was a group photo taken with White women and Black children in a courtyard.

Children being held. Four of these 13 photos from the aforementioned subset show a child being held by a White woman; this is an equal number to the photos showing a classroom setting. For example, one photo illustrates a White woman holding up a camera to show the display to the Black child grasping her arm. Both are looking down at the image and smiling, though the Black child's smile appears reserved, shy, or uncomfortable. Another image shows a White woman looking back and down at a small Black child who looks at the photographer with a sad or frightened look on his face. The composition of the photo is such that the White woman's face is blurred, emphasizing the child's expression. Considering this program is billed as a cross-cultural teaching experience, the equal photographic weight given to images showing a White woman holding a child-perhaps a student, the context is never provided-calls into question the intentions of the program. Based on these photos, a participant may expect to go to Africa to hold children and teach them in equal measure, and through both actions make change in a 'needy' community.

Women at center. Three of the 16 photos show mixed groups of children and adults. Two of those photos show a single White woman surrounded by Black children, presumably students. The most visually striking of these shows the White woman dressed in white and surrounded by Black 
children wearing shades of dark blue. Both the colors of the students' uniforms and their skin color highlights the disparity between teacher and student. The one photo which has multiple adults also is the only photo in the set which shows Black adults. In this photo, students stand in the front and adults in the back. Camaraderie is shown between adults based on body language (e.g. arms around each other) and the adults alternate White-Black. The exception to this is one White woman, cornrows in her hair, who crouches in front of one child to hover over two other children. That photo, depicting connections with non-White adults in a school setting, moves (most of) the White women to the back, in line with their local counterparts.

\section{Instruction}

Our findings revealed that few of the photos showed teaching or instruction, which was the focus of the program. It should be noted the breadth of educational contexts that are reflected in the photos but also variations that can exist across the larger educational landscapes in the countries and on the continent. It is possible that many students in South Africa and Tanzania would be similar but there are also differences that will exist among various demographic landscapes (e.g. urban, rural, etc.). We identified that most of the instructors were white females, which is consistent with literature that finds men are less likely to participate in study abroad programs.

Classroom. The most significant finding was that out of the 16 photos, only four were produced in classroom settings. One classroom image positioned the camera at the back the room, presenting the backs of three Black boys seated at desks on the right with the focal image of a White woman writing on a chalkboard in the front. Another, showing a large group photo, revealed the walls of the classroom covered with colorful posters and a bookshelf with what appeared to be dioramas of houses. Another shows bare walls painted a pale yellow, but shows students' desks overflowing with notebooks, papers, and other materials. A teacher's desk is also shown, stacked with a backpack, water bottle, and miscellaneous items. These images provide an incomplete picture of the teaching experience, but one that is recognizable to Westerners. The types of materials, resources, and seating are in line with Western educational methodologies exported globally during colonial times.

Teaching. Interestingly, only two of the four classroom photos showed a teaching moment. One of the photos, for example, shows a White woman in a purple t-shirt and a floor length purple floral skirt who stands in front of a classroom. Black children sit in desks. One child appears to be indicating another child, suggesting that dialogue is taking place in the classroom. The White woman, presumably a teacher, is holding a book or a sheaf of papers. Another photo showed students sitting on wooden desk with a White woman writing on a chalkboard. The board appears to be filled with geometry lessons, specifically chords. The age of the students is unclear, but they appear high school aged, and the content they are learning seems at that level as well. One student has his hand on his head and resting on the chair next to him. This photo is reproduced in our photo set; the second iteration--a poster in the College of Education--is presented with text reading, "Where will you make a difference?" above, and "Australia" and, in larger text, "Ghana," written below. The photo in question depicts a program in South Africa. 


\section{Environment}

This section of our findings discusses the environment in which the 16 photos were produced. We found that most of the photos were produced in a non-teaching and non-classroom environment. These photos show underdeveloped rural areas with dense forest and tangled vegetation. That said it should be noted the breadth of educational contexts that are reflected in the photos, but also variations that can exist across the larger educational landscapes in the countries and on the continent. It is possible that many students in South Africa and Tanzania would be similar but there are also differences that will exist among various demographic landscapes (e.g. urban, rural, etc.)

Non-teaching. Of the 16 photos in this study, 14 were produced in a non-teaching environment. One of the photos shows a group of students with three Black male and three White female teachers standing in what appears to be a dirty courtyard with one large tree that appears flush with a cinderblock wall behind the group. A similar photo also shows a group of Black students posed around a White woman in a courtyard. Some of the students are standing in the dirt and behind them two low buildings are visible. They are not clearly depicted. A few palm trees and other trees are visible in the courtyard and behind the buildings. Another interesting photo shows three Black students standing together, possibly outdoors. The student in the back faces the opposite direction of his peers, so his face is not visible. The others are smiling at something off in the distance and they all appear to be wearing school uniforms.

Non-classroom. Twelve of the 16 photos were produced outside of a classroom environment. However, nine of these twelve photos did not have any direct correlation with the Teach Abroad program (i.e., these did not depict apparent school settings or teaching occurring). A notable example is a photo of a forest that shows tree-covered hills sloping off into a foggy sky, with a giraffe's head and neck peeking out of the trees in the foreground. Text on the photo reads, in part: "After all, not many educators can say the very first time they were called a teacher was by students halfway around the globe in Tanzania." It is important to note that these students are not really qualified teachers but learners, nor are they prepared to responsibly act as teachers at this point. A second example, which at least located the participants at a significant tourist location in the country, depicts a group of 15 White women, six in the front crouched with their hands on their knees, eight behind them with their arms around each other, and one standing in the back. They are in front of a wooden sign, which identifies the location as the entrance to Serengeti National Park, a World Heritage Site. A grey, cloudy sky and three trees are visible behind the gate. These two photos were part of a publication highlighting the Teach Abroad program.

Poverty porn. One photo showed a light skinned brunette woman wearing a bright yellow tshirt, black pants and athletic shoes exiting a thatched hut. She is bent so far down that her knees nearly touch her chest. Her right arm is drawn across her body so she can exit, and she is clutching something to her chest with her left hand. The ground around the hut is dirt, but behind it there appears to be brush or grass. The hut is brown with a thatched roof, and appears small based on the apparent effort of the woman exiting it. This photo presented through the prism of cultural narratives plays into the White imagination by reinforcing preconceptions and clichés (i.e. primitive living conditions and facilities) about the African continent. Absent from this photo are the advancements Africans have made in their basic cultural facilities and a contextualized understanding 
of how voyeuristic consumption has influenced a longstanding trend of depicting Africa as an uncivilized backwards homogeneous place. The absence of such facilities suggests that Africans have not made any progress since their colonial masters left them. The implications are that Africans are still living in a primitive world.

\section{Conclusion}

As the state's flagship university, $\mathrm{CU}$ has a critical role in preparing the next generation of leaders for global competence. To meet these challenges, colleges and universities must commit to offering international study abroad experiences. While CU has an internationalization mission and is committed to developing global citizens, our study finds that TA's promotional materials continue to perpetuate an unbalanced representation of the African continent and its people. The images analyzed in this study are consistent with previous studies that portray non-Western environments as culturally inferior, stagnated, and needing of intervention by the West. Our findings show that these images do not disrupt, complicate, or challenge Western mass media stereotypes such as White Savior Complex and poverty porn.

The White Savior Complex suggests that Westerners come to African countries to "save" people largely through enthusiasm (Cole, 2012). In the context of the TA promotional materials, we see the White Savior Complex illustrated through photographic representations of White teachers educating in both non-White classrooms and non-classroom settings. In general, promotional materials showed White women - who are not yet teachers - in teaching roles, which suggests that there are no qualified Black teachers to fill those roles. While we understand that White women make up the majority of study abroad participants and teachers in the U.S., we note the absence of local teachers in promotional materials. We find this revealing considering there is a lack of experiential reciprocity in that rarely do we find untrained student foreigners in U.S. schools teaching children.

Keeping the postcolonial scholarship in mind, we noticed there are many photos where White women are at the center and Black students appear to not be engaged in their learning. Built into the White Savior Complex in an educational frame is the idea of the White Female Savior (Brown, 2013). All White participants shown in the 16 photos are women. In the two group photos depicting only White adults and children, the White women are at the center, surrounded by Black / African children who appear to be students. In these photos, the role of the White woman as a savior is depicted through racial distinctiveness and placing the woman at the center, but where Black adults are involved in photos, this symbolism is absent. This is particularly troubling because research literature on White women teachers in the U.S. finds that this group has little contact with Black adults (i.e. parents, teachers, and administrators) (Emdin, 2016), and we see Teach Abroad as an opportunity to advance an intellectual exchange with local educators while demonstrating global diversity and inclusion.

In this sense, these photos reflect the broader society's imagination about Africa as it relates to Western superiority. By continuing to polarize the West and Africa in promotional materials we find that higher education is in danger of doing what Caton and Santos (2009) referred to as binaries of modern-traditional, subject-object, and primitive-advanced. We find that these images de-complexify the globalization process by presenting the non-West as exotic, culturally pristine, and filled with 
happy natives. In the process higher education contributes to poverty porn - also known as development porn - which has been described as any type of media that utilizes the poor's condition in order to trigger the necessary sympathy or increasing charitable donations or support for a given cause (Kaskure \& Krivorotko, 2014).

One photo showed a group of Black children standing together, with a field behind them. Whereas children in classroom settings were wearing clean uniforms, these children were wearing dirty clothes and expressions of sadness, confusion, or concern. This image, offered without context, focused on the children's apparent pain and poverty. Another photo illustrating this theme showed a White woman bent at the waist, holding a camera, exiting a thatch hut. The visible background shows an expanse of field. Again, no context is offered for this photo, but it clearly presents an "othering" perspective suggesting poverty and lack. Another photo shows a White woman presenting a card to a group of Black children on a street. This photo seems to show teaching, occurring on a non-classroom setting, suggesting lack of resources for proper education.

We emphasize that colleges and universities should be concerned that American students have a poor understanding of the second largest continent, and make a commitment to promote healthy values of diversity and multiculturalism. If colleges are going to increase the number of students studying abroad in African countries, they must improve marketing and advertising. It is also important to provide a critical explanation of America's role in foreign policy in order for students to better understand the U.S. relations with the African continent. Therefore, pictures used in marketing brochures and presentations should be carefully selected to help counter stereotypical images. Lowe and colleagues (2008) argue that it is important to show contemporary images of "urban centers, transportation systems, society, culture, and art to juxtaposition widely circulated photos of subsistent living, civic conflict, and wild animals" (p. 738). Given the power of the West and its influence on framing of student's ideologies and perceptions of their societal positions, we call for the redirection of marketing and advertisements of African countries. Future research should continue to examine the depictions of African countries in promotional materials, and raise cultural awareness to issues concerning hegemony and culturalism. In doing so, scholar practitioners can be more mindful of how their marketing is negatively influencing the global framework of students and/or future leaders.

\section{Recommendations for Program Designers}

In this section we offer suggestions for program designers who are interested in implementing anti-oppressive approaches to study abroad. More specifically, we submit suggestions for phototaking in both pre-departure and for promotional materials. To this end, it is imperative to be intentional about instructing students on responsible photography.

\section{Pre-departure}

Program directors and students need to learn about the possible lenses that can be used to see others, so that they avoid a deficit, exoticized, touristic, or savior mentality. Program directors and students should be exposed to the regulations for picture taking in U.S. schools and the reasons why taking photos (especially of minors) is so tightly monitored and regulated. They can then consider the implications of their taking photos abroad and the subsequent use of those photos. Program directors should find out local regulations and customs regarding appropriateness of photographing 
people. They can be asked how they would like to be pictured. Explicit rules for taking photos—the when, where, who, what and why - should be shared with students. Program directors and students can consider the consequences of sharing their photos via social media. Do your students have a nuanced understanding of whiteness and colonialism (see Black Skin, White Mask by Frantz Fanon)?

\section{For promotion}

- Has permission been requested to use the photos? Were those photographed aware that their photos were taken and perhaps used for promotional purposes?

- Has "permission" been interrogated as it relates to power, culture, and relationship of host/locals to visitor(s)?

- Do the photos project the message of dignity and honor?

- Are the photographs/promotional materials shared with the community members who are pictured (that might influence which photos are used)?

- Who is in the role of agent/actor (i.e. U.S. students or the local population)?

- Are U.S. students represented with same-age peers or adult community members (teachers in this case)? Or only with children in a position of power?

- Do the images highlight positive identity representations? What messages about identity can be read through the images?

- Do the photos highlight community resources? What messages about local community resources can be read through the images?

- Are US students engaged in behavior that would be inappropriate in a U.S. school (such as holding children, excessive touching of children)?

- Could another image that depicts the goals/outcome of the project have been used?

- Do the images display real activities of the program—such as teaching, versus, staged photos?

- Do captions used with images display the program principles, or do they further a "saviormentality" agenda?

Designating a photo time and space avoids paparazzi-like moments where students voyeuristically take pictures of people without consent. To this end, we recommend talking with the partner host or institution prior to help set up an appropriate and designated space. For instance, posting signs that state "photographs and videos are being recorded (in local dialect)" brings awareness of what is happening and allows for people to have a choice in getting their picture taken. We recognize that traveling is exciting for students and program designers are thinking deeply about the role social media plays in students' experience in study abroad. Specifically, in this social media age that promotes the sharing of lived experience, it is imperative for program designers to incorporate culturally responsive and ethical ways of engaging with the global community. We have compiled the aforementioned checklist and guidelines to help campus professionals accomplish such goals. This is not an exhaustive list, and we desire for those interested in culturally responsible engagement to add and share widely. 


\section{References}

Albers, P. \& James, W. (1988). Travel photography: a methodological approach. Annals of Tourism Research, 15, 134-58.

Barthes, R. (1972). Mythologies. 1957. Trans. Annette Lavers. New York: Hill and Wang.

Bhabha, H. (1994). The location of culture. London: Routledge.

Bishop, S. C. (2013). The rhetoric of study abroad: Perpetuating expectations and results through technological enframing. Journal of Studies in International Education, 17(4), 398- 413. DOI: $10.177 / 1028315312472983$

Bolen, M. (2001). Consumerism and U.S. study abroad. Journal of Studies in International Education, 5(3), 182-200.

Brown, A. (2013). Waiting for superwoman: White female teachers and the construction of the neoliberal savior in a New York City public school. Journal for Critical Education Policy Studies, 11(2), 123164.

Buzinde, C., Santos, C. A., \& Smith, S. (2006). Ethnic representations: Destination imagery. Annals of Tourism Research, 33, 707-728.

Caton, K. \& Santos, C. A. (2009). Images of the other: selling study abroad in a postcolonial world. Journal of Travel Research, 48(2), 191-204. doi: 10.1177/0047287509332309

Caton, K. \& Santos, C. A., Images of the other: selling study abroad in a postcolonial world. Journal of Travel Research, 48(2), 191-204. doi: 10.1177/0047287509332309

Cole, T. (2012, March 21). The white-savior industrial complex. The Atlantic. Retrieved from http://www.theatlantic.com/international/archive/2012/03/the-white-savior-industrialcomplex/254843/

DeGraaf, D., Slagter, C., Larsen, K. \& Ditta, E. (2013). The long-term personal and professional impacts of participating in study abroad. Frontiers: The Interdisciplinary Journal of Study Abroad, 23, 42-59.

Douglas, T. M. O. (2016). Border crossing brothas: Black males navigating race, place, and complex space. New York, NY: Peter Lang.

Douglas, T. M.O., \& Nganga, C. (2015). What's radical love got to do with it: Navigating identity, pedagogy, and positionality in pre-service education. International Journal of Critical Pedagogy, 6(1), 58-82.

Downe-Wamboldt, B. (1992). Content analysis: Method, applications, and issues. Health Care for Women International, 13, 313-321.

Echtner, C. M., \& Prasad, P. (2003). The context of third world tourism marketing. Annals of Tourism research, 30(3), 660-682.

Emdin, C. (2016). For White Folks Who Teach in the Hood... and the Rest of Y'all Too: Reality Pedagogy and Urban Education. Boston, MA: Beacon Press.

Fanon, F., (1952) Black Skin, White Mask (2008) New York, Grove Press.

Geiser, J. D. (2015). Sociocultural investigation of identity: how students navigate the study abroad experience. Journal of College Student Development, 56(6), 637-643.

Glick, H. (2015, June 9). Bold new photo project tackles Appalachian poverty porn. Global Citizen. Retrieved from https://www.globalcitizen.org/en/content/bold-new-photo-project-tacklesappalachian-poverty/

Gresson, A. D., III. (2008). Race and education primer. New York: Peter Lang.

Hickey, D., \& Wylie, K. (1993). An enchanting darkness: The American vision of Africa in the twentieth century. East Lansing, MI: Michigan State University Press.

Hsieh, H. \& Shannon, S. (2005). Three approaches to qualitative content analysis. Qualitative Health Research, 15(9), 1277-1288.

Institute of International Education (2014). Fast facts Open Doors 2014. Retrieved from http://www.iie.org/research-and-publications/open-doors

Jenkins, O. (2003). Photography and travel brochures: the circle of representation. Tourism Geographies, $5(3), 305-28$. 
Kaskure, N., \& Krivorotko, J. (2014). Poverty porn as a sign of a postcolonial wall between "Us" and "Them". Retrieved from http://lup.lub.lu.se/luur/download?func=downloadFile\&recordOId=4460603\&fileOId=4460629

Kennedy, V. (2000). Edward Said: A critical introduction. Malden, MA: Blackwell Publishers Ltd. Khalifa, M., Douglas, T. M. O., \& Venzant-Chambers, T. (2016). White gazes of Black Detroit: Milliken v. Bradley, post-colonial theory, and why inequities persist. Teachers College Record, 118(3), 1-34.

Kiem, C. A. (2008). Mistaking Africa: Curiosities and inventions of the American mind. City: Westview Press.

Kitsantas, A. (2004). Studying Abroad: The role of college students' goals on the development of cross-cultural skills and global understanding. College Student Journal, 38(3), 441-452.

Lowe, T. B., Dozier, C. D., Hunt-Hurst, P. \& Smith, B. P. (2008). Study abroad in West Africa: An interdisciplinary program of international education. College Student Journal, 42(3), 738-747.

Luo, J. \& Jamieson-Drake, D. (2014). Predictors of study abroad intent, participation, and college outcomes. Research in Higher Education, 56(1), 29-56.

Mama, A. (2007). Is it ethical to study Africa? Preliminary thoughts on scholarship and freedom. African Studies Review, 50(1), 1-26.

Martin, F. \& Griffiths, H. (2012). Power and representation: A postcolonial reading of global partnerships and teacher development through North-South study visits. British Educational Research Journal, 38(6), 907-927.

McCarthy, M. (1983). Dark continent: Africa seen by Americans. Westport, CT: Greenwood Press.

Mukherjee, D. \& Chowdhury, D. (2014). What do the flyers say? Embedded 'orientalist'constructions in social work study abroad programs in the United States. International Social Work, 57(6), 576-589. DOI: $10.1177 / 0020872812441644$

National Center for Education Statistics (2013) Digest of Education Statistics. Retrieved from https://nces.ed.gov/programs/digest/d13/tables/dt13_209.10.asp

Onyenekwu, I. U. (2016). Traveling to Non-traditional Destinations: Recommendations for American Students Studying Abroad in "Africa". Mid-Western Educational Researcher, 28(1), 93-102.

Pires, M. (2000). Study-abroad and cultural exchange programs to Africa: America's image of a continent. African Issues, 28(1/2), 39-45.

Pritchard, A. (2000). Ways of seeing 'them' and 'us': tourism representation, race and identity. In Expressions of Culture, Identity and Meaning in Tourism (Eds.) M. Robinson, P. Long, N. Vans, R. Sharpley, \& J. Swarbrooke (245-262). Houghton-le-Spring, UK: Business Education Publishers.

Said, E. (1978). Orientalism. New York: Vintage.

Said, E. (2012). Culture and imperialism. New York: Vintage Books.

Salisbury, M. H., Umbach, P. D., Paulsen, M. B., \& Pascarella, E. T. (2009). Going global: Understanding the choice process of the intent to study abroad. Research in higher education, 50(2), 119-143.

Salisbury, M. H., Paulsen, M.B. \& Pascarella, E. T. (2010). To see the world or stay at home: Applying an integrated student choice model to explore the gender gap in the intent to study abroad. Research in Higher Education, 51(7), 615-640.

Spivak, G. C. (1990). The post-colonial critic: Interviews, strategies, dialogues. New York: Routledge.

Spivak, G. C. (1999). A critique of postcolonial reason: Toward a history of the vanishing present. Cambridge, MA: Harvard University Press.

Spivak, G. C., Landry, D., \& Maclean, G. (Eds.). (1996). The Spivak reader. New York: Routledge.

Tolliver, D. E. (2000). Study abroad in Africa: Learning about race, racism, and the racial legacy of America. African Issues, 28(1/2), 112-116. doi:10.2307/1167071

Villaverde, L. E. (2008). Feminist theories and education primer. New York: Peter Lang.

Williams, T. R. (2005). Exploring the impact of study abroad on students' intercultural communication skills: adaptability and sensitivity. Journal of Studies in International Education, 9(4), 356-371. doi: $10.1177 / 1028315305277681$ 
Ifeyinwa Onyenekwu, Julianne Marie Angeli, Ransford Pinto, Ty-Ron Douglas

Woolf, M. (2006). Come and see the poor people: The pursuit of exotica. Frontiers: The Interdisciplinary Journal of Study Abroad, 13, 135-146.

Wynveen, C. J., Kyle, G. T. \& Tarrant, M. A. (2012). Study abroad experiences and global citizenship: fostering pro-environmental behavior. Journal of Studies in International Education, 16(4), 334-352. doi: $10.1177 / 1028315311426782$ 